\title{
Macrophage colony-stimulating factor and its receptor signaling augment glycated albumin- induced retinal microglial inflammation in vitro
}

\author{
Wei Liu', Ge Z Xu ${ }^{1,2^{*}}$, Chun H Jiang ${ }^{1}$, Jie Tian ${ }^{1}$
}

\begin{abstract}
Background: Microglial activation and the proinflammatory response are controlled by a complex regulatory network. Among the various candidates, macrophage colony-stimulating factor (M-CSF) is considered an important cytokine. The up-regulation of M-CSF and its receptor CSF-1R has been reported in brain disease, as well as in diabetic complications; however, the mechanism is unclear. An elevated level of glycated albumin (GA) is a characteristic of diabetes; thus, it may be involved in monocyte/macrophage-associated diabetic complications.

Results: The basal level of expression of M-CSF/CSF-1R was examined in retinal microglial cells in vitro. Immunofluorescence, real-time PCR, immunoprecipitation, and Western blot analyses revealed the up-regulation of CSF-1R in GA-treated microglial cells. We also detected increased expression and release of M-CSF, suggesting that the cytokine is produced by activated microglia via autocrine signaling. Using an enzyme-linked immunosorbent assay, we found that GA affects microglial activation by stimulating the release of tumor necrosis factor- $\alpha$ and interleukin-1 $\beta$. Furthermore, the neutralization of M-CSF or CSF-1R with antibodies suppressed the proinflammatory response. Conversely, this proinflammatory response was augmented by the administration of M-CSF.

Conclusions: We conclude that GA induces microglial activation via the release of proinflammatory cytokines, which may contribute to the inflammatory pathogenesis of diabetic retinopathy. The increased microglial expression of M-CSF/CSF-1R not only is a response to microglial activation in diabetic retinopathy but also augments the microglial inflammation responsible for the diabetic microenvironment.
\end{abstract}

\section{Background}

Recent evidence strongly suggests that microglial activation plays a central role in the inflammation induced by experimental and human retinopathy [1-4]. Microglia, the resident macrophages of the central nervous system (CNS), is sensitive to minute changes in their microenvironment and is quickly activated. Upon activation, they proliferate and become amoeboid phagocytotic cells that produce a variety of proinflammatory cytokines, nitric oxide $(\mathrm{NO})$, and reactive oxygen intermediates [5-7]. These factors are well known to induce neurodegeneration, although the precise mechanism is not fully understood.

\footnotetext{
* Correspondence: xugezhi@sohu.com

'Department of Opthalmology, EENT Hospital, Eye Institute, Fudan University, Shanghai, 200031, China

Full list of author information is available at the end of the article
}

Recently, Wang et al. [8] reported that glycated albumin (GA) significantly enhanced the production and release of tumor necrosis factor- $\alpha$ (TNF- $\alpha$ ) from retinal microglia in vitro, suggesting that GA contributes to microglial inflammation in diabetic retinopathy. Chronic hyperglycemia in diabetes, through the nonenzymatic glycation of free amino groups in proteins by glucose, leads to the formation of labile Schiff base intermediates that undergo Amadori rearrangement, leading to the relatively stable early adducts ketoamine or fructosamine (so-called Amadori products). Eventually, these Amadori products form irreversible advanced glycation end products (AGEs) [9]. Glycated albumin levels increase drastically under diabetic conditions, and the plasma levels of GA may vary from normal $(400 \mu \mathrm{g} / \mathrm{mL})$ to diabetic $(1000 \mu \mathrm{g} / \mathrm{mL})$ [10]. Increasing evidence suggests that early glycated albumin is not just an index of glycemia or the precursor of AGEs. By itself, it may have direct
C Biomed Central

() 2011 Liu et al; licensee BioMed Central Ltd. This is an Open Access article distributed under the terms of the Creative Commons Attribution License (http://creativecommons.org/licenses/by/2.0), which permits unrestricted use, distribution, and reproduction in any medium, provided the original work is properly cited. 
impacts on cellular functions and thus may play a pathophysiological role in microvascular complications of diabetic nephropathy and retinopathy [11-14]. Glycated albumin accumulates in the diabetic retina [14-16] and changes the local concentrations of cytokines, growth factors, and other bioactive molecules by binding on several cell types, such as retinal pigment epithelium cells $[17,18]$ and monocytes/macrophages $[19,20]$, and by inducing the secretion of proinflammatory cytokines via the activation of protein kinase $\mathrm{C}$ (PKC), nuclear factor $-\kappa \mathrm{B}(\mathrm{NF}-\kappa \mathrm{B})$, protein tyrosine kinase (PTK), and activator protein-1 (AP-1) signaling [21,22]. Therefore, GA may have important effects on the initiation and progression of diabetic retinopathy.

Macrophage colony-stimulating factor (M-CSF) is one of the most important substances known to affect macrophage physiology. The binding of M-CSF to its sole specific receptor, CSF-1R, stimulates the survival, proliferation, and differentiation of mononuclear phagocytes $[23,24]$. Moreover, M-CSF is considered a key cytokine in the regulation of microglial inflammatory responses [25]. Accumulating evidence suggests the upregulation of M-CSF accompanied by the strong and selective induction of CSF-1R in activated microglia following brain damage caused by injury or disease such as brain ischemia or Alzheimer's disease [26-29]. In vitro, microglial overexpression of CSF-1R augments phagocytosis and contributes to the inflammatory response $[30,31]$. Similar patterns of M-CSF/CSF-1R expression have also been reported in the diabetic environment, suggesting that M-CSF/CSF-1R signaling plays a critical role in the pathogenesis of diabetic lesions $[32,33]$. The exact mechanism, however, is unclear.

Given the small amount of information available concerning CSF-1R expression by microglia in the diabetic environment, the regulatory role of M-CSF/CSF-1R signaling in microglial inflammation in diabetic retinopathy is unknown. In the present study, we sought to ascertain whether GA has an effect on retinal microglial activation, including the production of proinflammatory cytokines, as well as the expression of M-CSF and its receptor CSF$1 R$. Furthermore, using exogenous M-CSF and antibody neutralization, we assessed the combined effect of M-CSF and GA on the proinflammatory response in primary microglial cells. Our results indicate that M-CSF acts as a costimulatory molecule to synergize GA-induced microglial inflammation via binding to its overexpressed receptor CSF-1R in diabetic retinopathy.

\section{Results}

Morphology and characterization of cultured newborn rat microglia

After 7 to 8 days of mixed-cell culture, the microglia appeared in small colonies (about 2 to 5 cells) of highly refractive cells above the basal macroglial layer. These round microglial cells or colonies were loosely attached to the macroglial monolayer; maximum proliferation was observed within 10 to 12 days. The purified microglial cells went from being amoeboid in shape to having a ramified shape, with a single long process and a small cell soma, over the course of 2 to 3 days. Immunofluorescence analysis revealed that OX-42-positive microglial cells accounted for $95 \%$ of the harvested cells, whereas none of the cells was positive for GFAP.

\section{Effects of various agents on microglial viability by MTT assay}

M-CSF-induced microglial proliferation in a dosedependent manner was confirmed, in which the extent of microglial proliferation correlated well with the increase of the viability measured by MTT assay. In contrast to M-CSF, GA didn't induce significant proliferation (Figure 1A). Furthermore, the microglial apoptosis was observed when the concentration of GA exceeds $1000 \mu \mathrm{g} / \mathrm{mL}$. In addition, the antibodies of either M-CSF or CSF-1R have no effect on microglial viability by MTT assay (Figure 1B).

\section{GA causes morphological changes in microglial cells}

As shown in Figure 2, the unstimulated microglia had a ramified shape in vitro (Figure $2 \mathrm{~A}$ ). In contrast, the GA-stimulated microglia was bigger and rounder, with the appearance of activated cells (Figure 2B).

\section{Effect of GA on the expression of microglial Iba1}

Iba1, a microglia-specific calcium-binding protein and marker of activated microglia, is involved in motility, phagocytosis, and proinflammation in activated microglia via the regulation of the actin cytoskeleton [34]. In this study, we observed enhanced Ibal expression in GA-stimulated microglia compared with unstimulated cells. In addition, following $24 \mathrm{~h}$ of stimulation with GA, Iba1 was translocated from the cytoplasm to membrane ruffles (Figure 2C, 2D).

\section{GA-induced release of TNF- $\alpha$ and interleukin (IL)- $1 \beta$ from activated microglia}

Following stimulation with $10 \mu \mathrm{g} / \mathrm{mL}$ GA for $6 \mathrm{~h}$, a significant increase in the release of TNF- $\alpha$ was detected compared with the control group (38.7 \pm 3.2 vs. $19.7 \pm$ $1.7 \mathrm{pg} / \mathrm{mL} ; \mathrm{P}<0.05)$. Moreover, GA induced the dosedependent release of TNF- $\alpha$, with a peak at $250 \mu \mathrm{g} / \mathrm{mL}$ $(138.2 \pm 6.6 \mathrm{pg} / \mathrm{mL} ; \mathrm{P}<0.0001)$. There was a slight increase in the release of TNF- $\alpha$ from 6 to 24 h; however, no statistically significant difference was found among the various groups (Figure 3A). Similarly, GA induced the dose-dependent release of IL-1 $\beta$. Different from the release of TNF- $\alpha$, the increase of IL- $1 \beta$ 

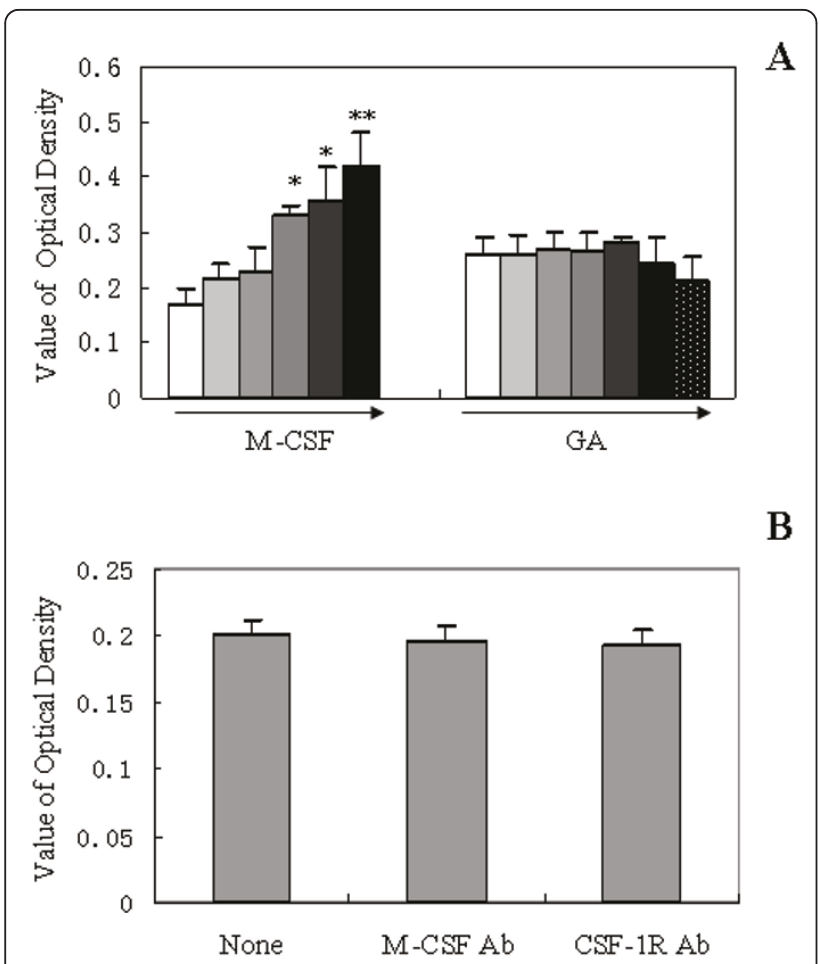

Figure 1 Effect of M-CSF, glycated albumin (GA) and the antibodies of either M-CSF(anti-M-CSF Ab)or CSF-1R(anti-CSF$1 R \mathbf{A b}$ ) on microglial viability. After incubated with various stimuli such as M-CSF or GA (A), and anti-M-CSF Ab $(1 \mu \mathrm{g} / \mathrm{ml})$ or anti-CSF$1 \mathrm{R} \mathrm{Ab}(1 \mathrm{\mu g} / \mathrm{ml})$ (B) for $24 \mathrm{~h}$, the cell viability was assessed by MTT assay. The gradient concentrations of stimuli were: 5, 10, 25, 50, 100 $\mathrm{ng} / \mathrm{ml}$ for M-CSF; and 10, 50, 100, 500, 1000, $2000 \mu \mathrm{g} / \mathrm{ml}$ for GA. The results are shown as means \pm SD of three individual experiments. Only M-CSF induced microglial proliferation in a dose-dependent manner, other agents have no effects on microglial viability. Oneway ANOVA was performed, followed by post-hoc analysis. ${ }^{*}, \mathrm{P}<$ $0.05 ;{ }^{* *}, P<0.005$.

following stimulation with $10 \mu \mathrm{g} / \mathrm{mL}$ GA was not significant compared with that in the control group until after $12 \mathrm{~h}(78.1 \pm 3$ vs. $50.8 \pm 6.8 \mathrm{pg} / \mathrm{mL} ; \mathrm{P}<0.05)$. The release of IL-1 $\beta$ peaked at $261.3 \pm 11.4 \mathrm{pg} / \mathrm{mL}$ following $12 \mathrm{~h}$ of stimulation with $250 \mu \mathrm{g} / \mathrm{mL}$ GA $(\mathrm{P}<0.0001)$; however, no statistically significant difference was found among the various groups (Figure 3B). Neither TNF- $\alpha$ nor IL-1 $\beta$ production by activated microglia stimulated with GA could be prevented by the endotoxin binding polypeptide polymyxin B (PMXB) at $10 \mu \mathrm{g} / \mathrm{mL}$, a dosage previously reported to abrogate LPS-induced effects on microglia [35] (Figure 4).

\section{GA-induced production of M-CSF by activated microglia}

$M-C S F$ production occurs via autocrine signaling in activated microglia. To determine whether GA could induce microglial production of M-CSF, we analyzed the amount of M-CSF in the microglial culture medium.
After stimulation with 10 or $250 \mu \mathrm{g} / \mathrm{mL}$ GA for $24 \mathrm{~h}$, a significant increase in M-CSF release $(86.4 \pm 4.8$ or $97.4 \pm$ $7.3 \mathrm{pg} / \mathrm{mL}$, respectively) was detected, compared with the control $(54.8 \pm 1.6 \mathrm{pg} / \mathrm{mL})(\mathrm{P}<0.05$; Figure 5$)$.

\section{GA-induced up-regulation of CSF-1R and tyrosine- phosphorylation of CSF-1R by activated microglia}

Previous studies showed that CSF-1R expression is enhanced in activated microglia and that this up-regulation not only induces the microglial production of proinflammatory cytokines but also promotes the phagocytosis of amyloid $\beta(A \beta)$. We analyzed the effect of GA on CSF-1R expression in microglia. CSF-1R mRNA was detected in unstimulated microglia; however, after $24 \mathrm{~h}$ of stimulation with 10,250 , or $500 \mu \mathrm{g} / \mathrm{mL} \mathrm{GA}$, the level of CSF-1R mRNA expression was increased 1.2-, 2.1 -, and 2.6-fold, respectively ( $\mathrm{P}<0.05$; Figure 6 ).

To examine the effect of GA on CSF-1R signaling, we incubated microglial cells with 0,250 , or $500 \mu \mathrm{g} / \mathrm{mL}$ GA for $24 \mathrm{~h}$, and then subjected them to immunoprecipitation and immunoblot analysis. Our results indicate that both CSF-1R and phosphorylation of CSF-1R (tyr273) was up-regulated by GA-activated microglia (Figure 7).

Immunocytochemical analysis further demonstrated that GA induces the expression of CSF-1R (Figure 8A, $8 \mathrm{~B}$ ), as well as M-CSF (Figure 8C, 8D), in activated microglia. As shown in Figure 8, enhanced staining was observed in the GA-stimulated round amoeboid microglia, whereas weak staining was detected in the unstimulated ramified microglia.

\section{Inhibition of M-CSF or CSF-1R signaling suppresses GA-induced microglial inflammation}

We next tested our hypothesis that M-CSF/CSF-1R signaling promotes the release of proinflammatory cytokines in GA-stimulated microglia. We neutralized the activity of M-CSF or CSF-1R by using anti-M-CSF or anti-CSF-1R antibodies. The neutralization of M-CSF or CSF-1R had no effect on unstimulated microglia; however, both antibodies decreased the release of TNF- $\alpha$ and IL-1 $\beta$ from the GA-stimulated microglia (Figure 9).

\section{M-CSF augments GA-induced microglial inflammation}

To further understand the combined effects of M-CSF and GA on the proinflammatory response in microglial cells, we included M-CSF in the microglial culture medium. M-CSF alone did not induce cytokine release; however, costimulation with M-CSF and GA for $24 \mathrm{~h}$ produced a significant increase in the release of TNF- $\square$ and IL-1 $\beta(P<0.05$; Figure 9).

\section{Discussion}

Inflammation involving vessels and neural tissue occurs early in diabetic retinopathy, while excessive and 

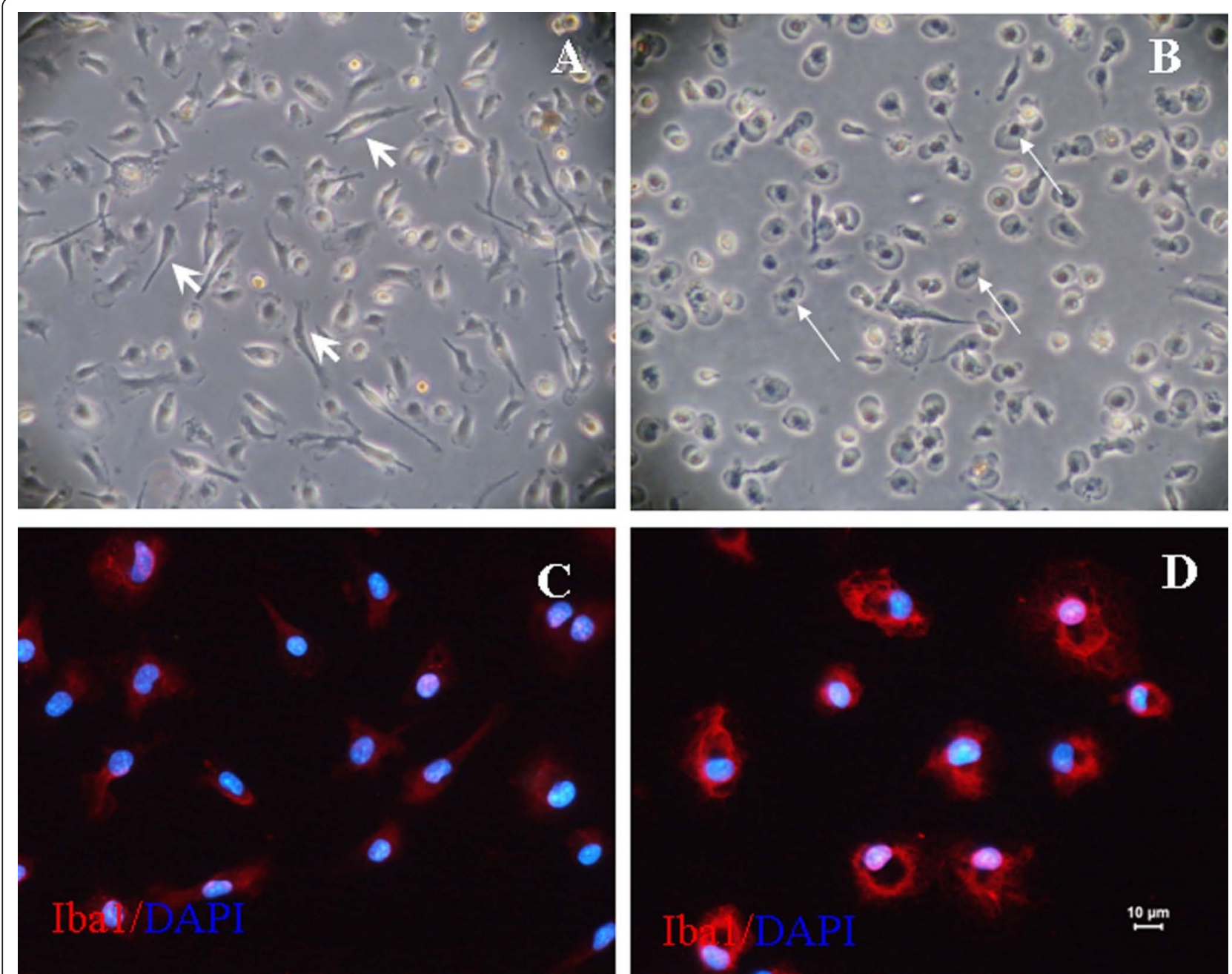

Figure 2 Effect of glycated albumin (GA) on cultured retinal microglial cells. (A) Phase-contrast image of purified retinal microglial cells after $72 \mathrm{~h}$. The cells have a ramified shape, with a single long process and a small cell body (short arrow). (B) Following exposure to $250 \mu \mathrm{g} / \mathrm{mL}$ GA for $24 \mathrm{~h}$, the cells became rounder, larger, and amoeboid in shape (long arrow) (original magnification: $\times 100)$. (C) Microglial cells without GA exposure show weak Iba1 immunofluorescence (red) in the cytoplasm. (D) Following exposure to $250 \mu \mathrm{g} / \mathrm{mL}$ GA for 24 h, Iba1 expression was up-regulated, and the protein was translocated to membrane ruffles. The nuclei of the microglia are labeled with DAPI (blue).

persistent microglial activation is believed a major contributor to the inflammatory responses [2,36,37]. Microglial activation occurs via a complex regulatory system involving multiple signals; however, the mechanism remains to be determined.

Amadori-glycated proteins and the early nonenzymatic glycation of proteins are increased in diabetes and have been independently associated with microvascular complications $[14,15,38]$. As the breakdown of the blood-retinal barrier (BRB) is a characteristic early event, the increased GA in plasma may penetrate from the compromised $\mathrm{BRB}$ and accumulate in retinal parenchyma, influencing the types of retinal cells and molecular mediators that subsequently promoting the development of diabetic retinopathy $[17,18,39,40]$. Our data suggested that in vitro GA activate microglia, producing proinflammatory factors. This event may be expected to occur in vivo, thereby aggravate the pathological inflammatory process. It was supported by the recent investigation that inhibiting the formation of GA would ameliorate the development of diabetic retinopathy [15].

The GA used in this study was produced commercially less than 1 week prior and purified to exclude residual contamination with AGEs as described by Baynes et al [41]. In contrast to AGEs, only a few studies have emphasized the role of GA, despite the fact that the Amadori product is a major form of glycated proteins and the concentration of GA exceeds that of AGEs [14,42]. Amadori-modification is structurally distinct from AGEs, and can bind to monocytes/ 


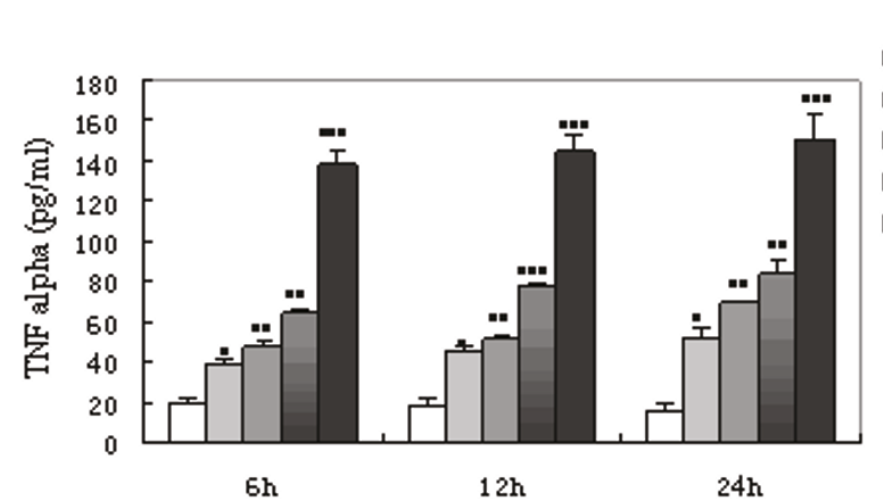

$\square$ Cont.

$\mathbf{A}$

$\square$ 10ug/ml

$\square 50 \mathrm{ug} / \mathrm{ml}$

$\square 100 \mathrm{ug} / \mathrm{ml}$

口 $250 \mathrm{ug} / \mathrm{ml}$

$6 h$

$12 \mathrm{~h}$

$\square$ Cont. B

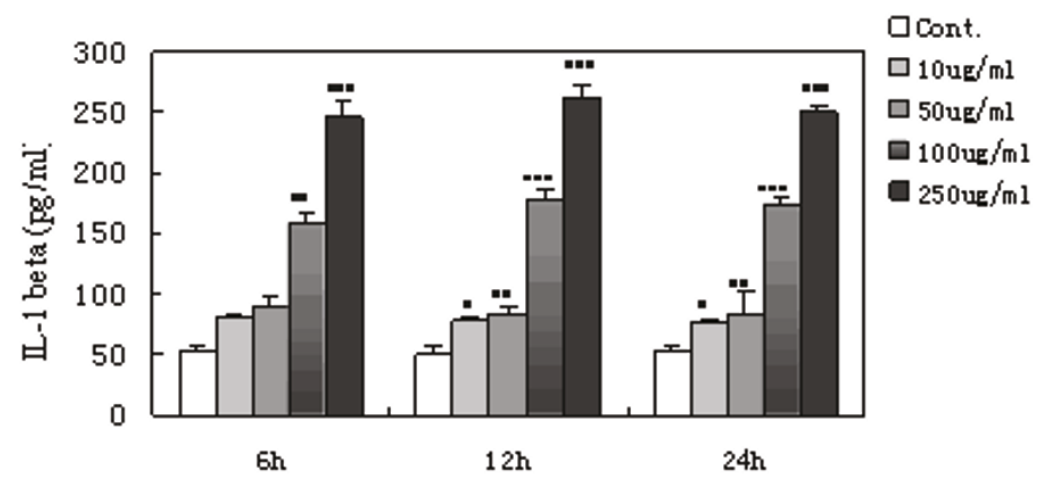

Figure 3 Cytokine release from purified microglial cells stimulated with glycated albumin (GA) for $6, \mathbf{1 2}$, or $\mathbf{2 4}$ h. (A) The release of TNF- $\alpha$ from retinal microglial cells cultured with $0,10,50,100$, or $250 \mu \mathrm{g} / \mathrm{mL}$ GA for various time periods. TNF- $\alpha$ in the culture supernatants began to increase at $6 \mathrm{~h}$ after exposure to $10 \mu \mathrm{g} / \mathrm{mL}$ GA and peaked after exposure to $250 \mu \mathrm{g} / \mathrm{mL}$ GA. (B) The release of IL-1 $1 \beta$ from retinal microglial cells cultured with $0,10,50,100$, or $250 \mu \mathrm{g} / \mathrm{mL}$ GA for various time periods. IL-1 $\beta$ in the culture supernatants began to increase at $12 \mathrm{~h}$ after exposure to $10 \mu \mathrm{g} / \mathrm{mL}$ GA and peaked after exposure to $250 \mu \mathrm{g} / \mathrm{mL} \mathrm{GA}$. The results are shown as means \pm SD of three individual experiments. One-way ANOVA was performed, followed by post-hoc analysis. ${ }^{*}, \mathrm{P}<0.05$; ${ }^{* *}, \mathrm{P}<0.001$; ${ }^{* * *}, \mathrm{P}<0.0001$.

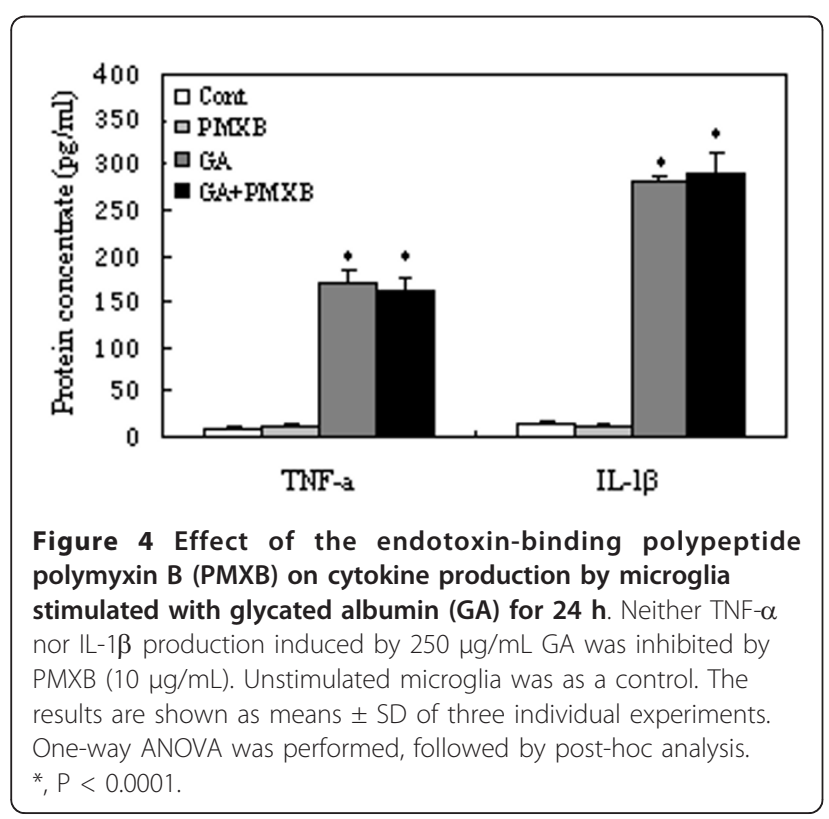

macrophages via specific receptors $[19,20]$. These receptor proteins have been characterized and the amino acid sequence homologies were not found in any of the AGE receptors [19-21,43]. Therefore, it is reasonable that binding of GA to microglia via specific receptors rather than receptors of AGEs, induced microglial activation.

Accumulating evidences showed M-CSF is a key cytokine in the regulation of the microglial activation, proliferation and migration in CNS [23-25]. Moreover, the high-affinity binding of M-CSF to CSF-1R plays a role in mononuclear/macrophage-associated diabetic complications, including diabetic retinopathy $[32,33,44,45]$. Our previous study provided the evidence that the vigorous expression of M-CSF/CSF-1R occurred in the early diabetic retina and a robust induction of CSF-1R was observed on the activated microglia [46]. Furthermore, as shown in the current study, primary retinal microglial cells express either CSF-1R or M-CSF, albeit at relatively low baseline levels. While they were exposed to gradient 


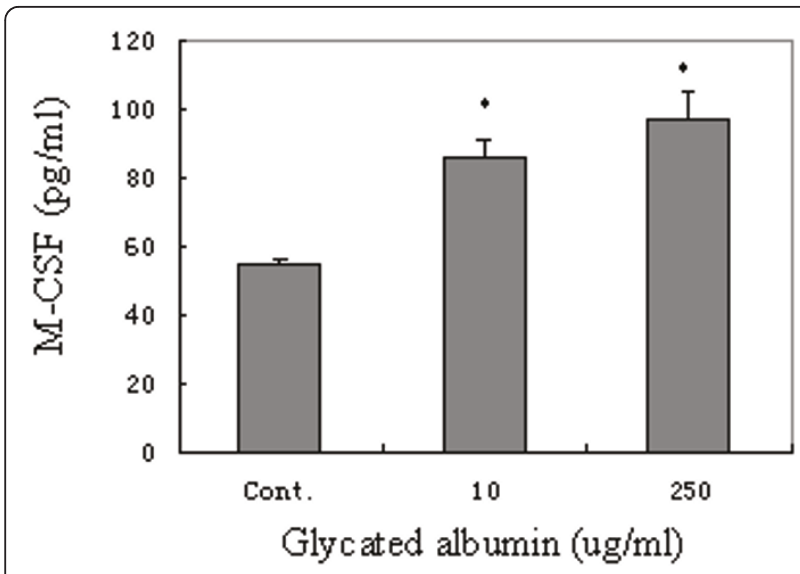

Figure $5 \mathrm{M}$-CSF release from purified microglial cells stimulated with 0,10 , or $250 \mu \mathrm{g} / \mathrm{mL}$ glycated albumin (GA) for $24 \mathrm{~h}$. GA significantly induces the release of M-CSF, compared with the control. The results are shown as means \pm SD of three individual experiments. One-way ANOVA was performed, followed by post-hoc analysis. *, $\mathrm{P}<0.05$.

concentrations of GA, the enhanced expression of CSF$1 \mathrm{R}$ signaling was detected in activated microglia, not only at the mRNA but also at the protein level. This upregulation is consistent with that as seen in vivo, and may be integral to diabetic microglial activation [46]. In light of the above findings, we hypothesize that M-CSF signaling is a possible molecular pathway in diabetic retinopathy.

To further our understanding, we measured the amounts of TNF- $\alpha$ and IL- $1 \beta$, two important proflammatory cytokines secreted by activated microglia, in GA-stimulated microglial cultures treated with or

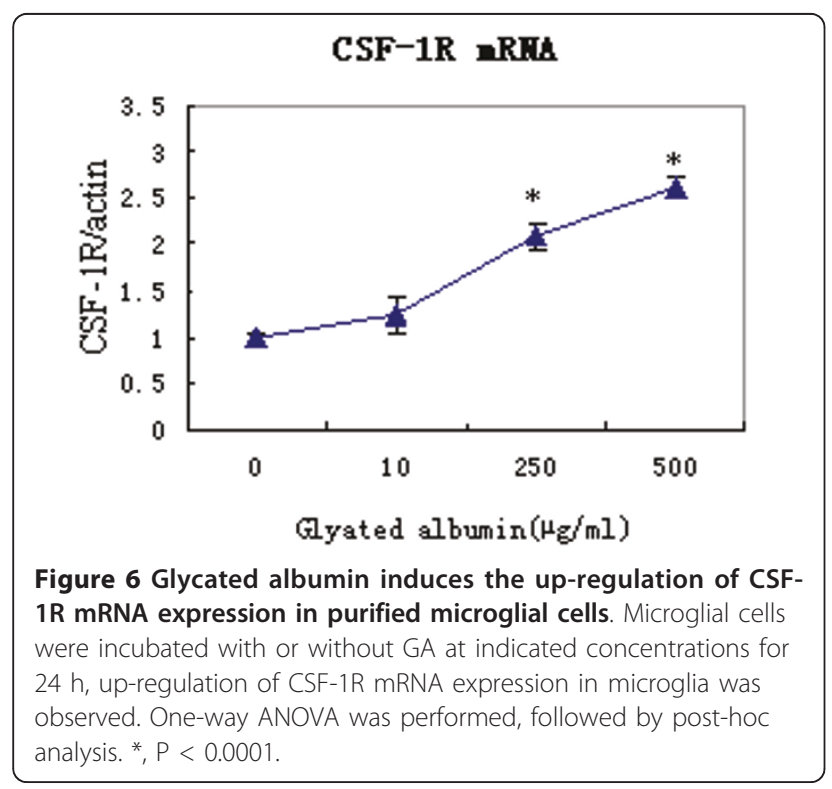

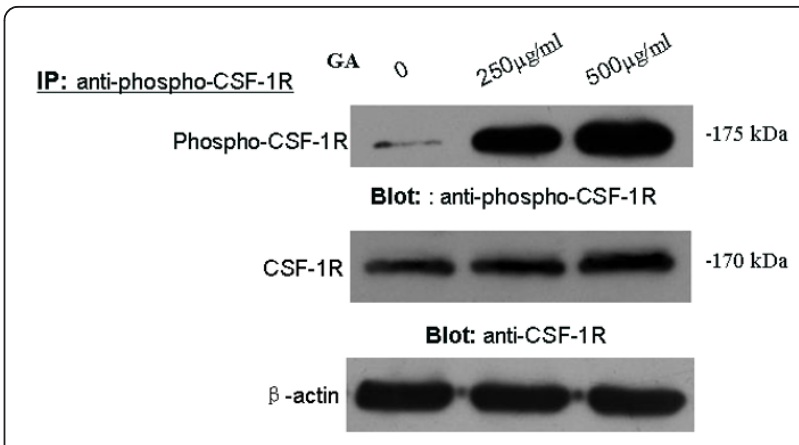

Figure 7 Glycated albumin (GA) induces the up-regulation of CSF-1R and tyrosine-phosphorylation of CSF-1R in purified microglial cells. Microglial cells were incubated with or without GA for $24 \mathrm{~h}$ and then subjected to immunoprecipitation (IP) with antibodies against phospho-CSF-1R(Tyr723) and then blot with antibodies against phospho-CSF-1R(Tyr723) or CSF-1R. The expression of $\beta$-actin was used as loading control.

without additional M-CSF. Our results show that MCSF enhances the production of proflammatory cytokines in GA-activated microglia. M-CSF alone, however, did not induce the proinflammatory responses but proliferate microglia as shown by MTT assay. Although theoretically, more cells due to M-CSF treatment may contribute to more cytokine production, given the fact that this inducible proinflammation could be significantly inhibited by antibody neutralization of M-CSF or CSF-1R, and the fact that GA enhanced expression of M-CSF/CSF-1R by microglia, it is reasonable that this is quite far from the actual synergistic effects of the two agents. Taken all together, we concluded that M-CSF may be a co-stimulator with GA and that M-CSF/CSF$1 R$ signaling exerts a synergistic effect with GA on the production of proinflammatory cytokines, not simply due to effects on cell proliferation.

Astrocytes, a major source of M-CSF in CNS, can be induced to release M-CSF by proinflammatory cytokines [47-50]. However, note that M-CSF is also secreted by activated microglial cells $[26,28]$. Moreover, as determined by immunocytochemistry and ELISA, the level of M-CSF elevates in GA-stimulated-microglia. Elevated M-CSF expression could cause further reactive microgliosis, phagocytosis, and the release of inflammatory cytokines such as IL-1 $\beta$, IL-6, and M-CSF [23-25]. Thus, the present study provides evidence for the roles of $\mathrm{M}-\mathrm{CSF}$ and its signaling cascade in activated microglia in response to GA stimulation, suggesting that M-CSF is an important cross-talk mediator, involved in astrocytes, neurons, and microglia.

\section{Conclusions}

In summary, it is evident that GA can induce microglial activation by stimulating the release of proinflammatory 

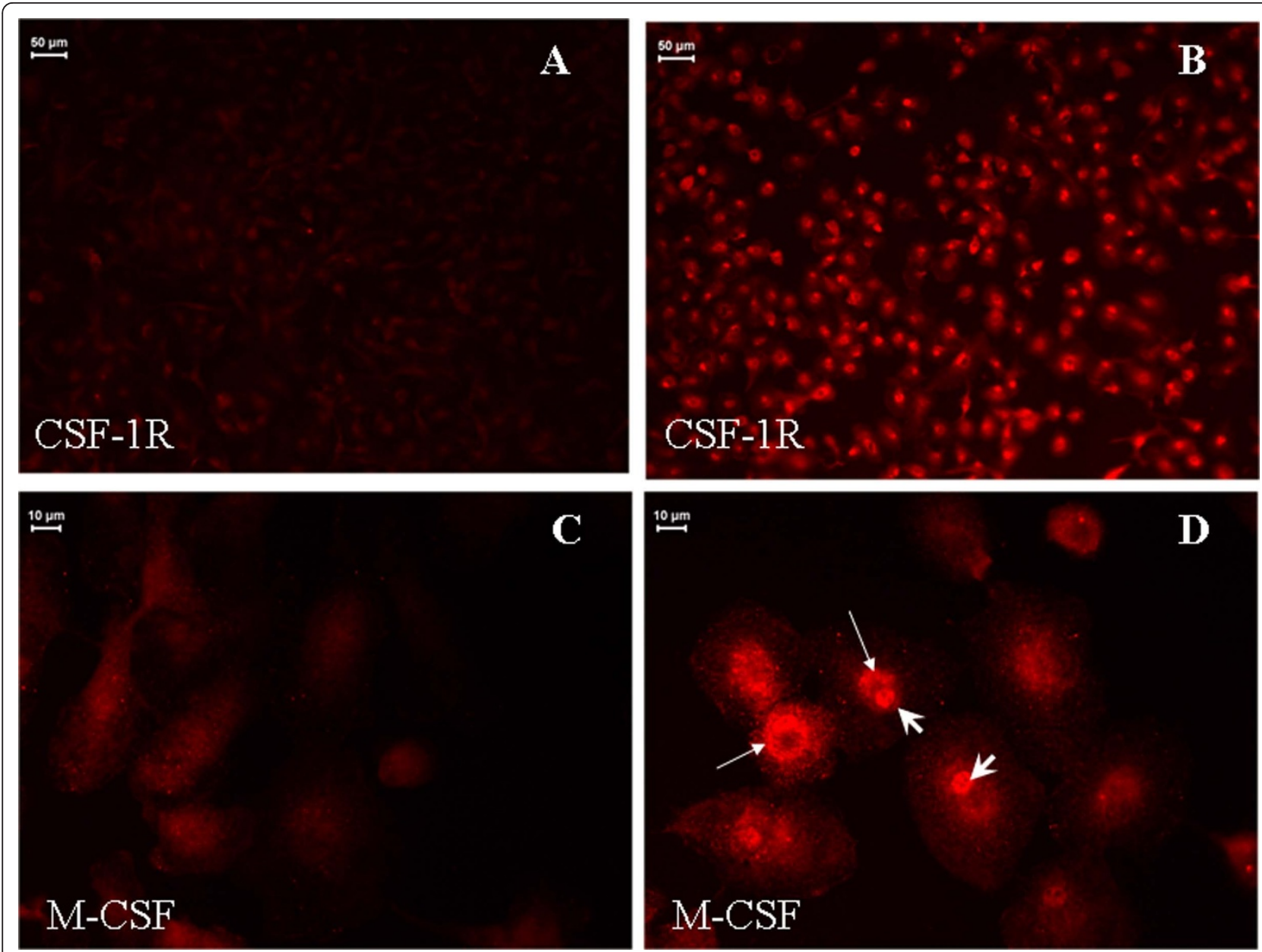

Figure 8 Effect of glycated albumin (GA) on microglial CSF-1R and M-CSF expression. (A) Without GA exposure, microglial cells exhibited weak CSF-1R immunofluorescence in the cytoplasm. (B) Following exposure to $250 \mu \mathrm{g} / \mathrm{mL}$ GA for $24 \mathrm{~h}$, the expression of CSF-1R was clearly upregulated. (C) Similarly, weak M-CSF immunofluorescence was observed in the cytoplasm without GA treatment. (D) Following exposure to 250 $\mu \mathrm{g} / \mathrm{mL}$ GA for $24 \mathrm{~h}$, the expression of M-CSF was up-regulated; the signal was detected in both the cytoplasm (long arrow) and nucleus (short arrow) of each cell.

cytokines such as TNF- $\alpha$ and IL-1 $\beta$ in vitro. Simultaneously, up-regulation of CSF-1R on microglia may augment the overall inflammatory response by propagating the proinflammatory signal to nearby resting microglia and astrocytes. The binding of M-CSF to overexpressed CSF-1R seems to augment GA-induced microglial inflammation via autocrine and paracrine effects, which can be blocked by antibody neutralization. Our present study demonstrate that M-CSF/CSF-1R signaling represents a further link between microglial inflammation and diabetic retinopathy and raises the possibility of specific therapies for targeting microglia-mediated injury in diabetic retinopathy. Further work are required for a better understanding of the molecular mechanisms underlying M-CSF/CSF-1R signaling in microglia activation.

\section{Methods}

\section{Primary Retinal Microglial Culture}

Primary mixed glial cell cultures were prepared as described previously with modifications $[51,52]$. In brief, fresh retinas were obtained from newborn Sprague-Dawley rats (2-3 days old). Animal care procedures and the experimental protocol complied with the Guidelines of the Ethics Committee at Fudan University. The retinas were placed on ice in $\mathrm{Ca}^{2+}$ - and $\mathrm{Mg}^{2}$ ${ }^{+}$-free Hank's balanced salt solution after removal of the blood vessels. The tissues were then minced and exposed to $0.25 \%$ trypsin-EDTA (Invitrogen, Carlsbad, $\mathrm{CA})$ at $37^{\circ} \mathrm{C}$ for $8 \mathrm{~min}$. After terminating the digestion with fetal bovine serum (FBS, Invitrogen), the cells were collected by centrifugation, re-suspended in Dulbecco's modified Eagle's medium (DMEM)/F12 (1:1) 


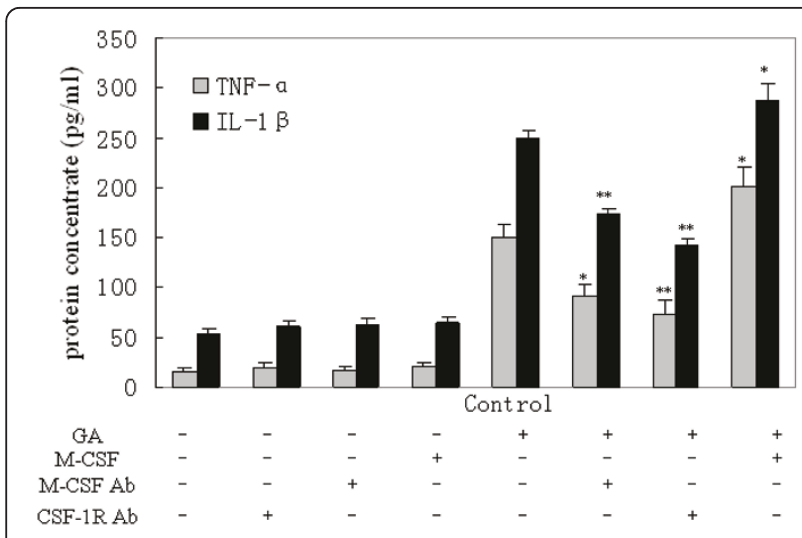

Figure 9 Release of TNF- $\alpha$ and IL-1 $\beta$ from microglia following the neutralization of M-CSF or CSF-1R, or the administration of M-CSF. None of the above had a significant effect on cytokine release in the groups without glycated albumin (GA) stimulation. The neutralization of M-CSF $(1 \mu \mathrm{g} / \mathrm{mL})$ or CSF-1R $(1 \mu \mathrm{g} / \mathrm{mL})$ suppressed TNF- $\alpha$ and IL-1 $\beta$ release in the experimental group (cells treated with $250 \mu \mathrm{g} / \mathrm{mL}$ GA for $24 \mathrm{~h}$ ). Treatment with $100 \mathrm{ng} / \mathrm{mL} \mathrm{M}$ CSF augmented the GA-induced release of TNF- $\alpha$ and IL-1 $1 \beta$. Oneway ANOVA was performed, followed by post-hoc analysis. ${ }^{*}, \mathrm{P}<$ 0.05 ; **, $P<0.001$, compared with the control group.
(Invitrogen) supplemented with 10\% FBS, penicillin/ streptomycin $(100 \mathrm{U} / 100 \mu \mathrm{g}$ per $\mathrm{mL})$, and L-glutamine $(2 \mathrm{mM})$, and plated on poly L-lysine-coated (SigmaAldrich, St. Louis, MO) T75 flasks at a density of $1.2 \times$ $10^{6}$ cells $/ \mathrm{mL}$. The culture medium was changed after 3 days and then twice a week. Upon confluence (7-10 days), the microglial cells were harvested by the "shaking-off" method (an initial shake at $100 \mathrm{rpm}$ for 30 min followed by a second shake 7 days later). The purified microglial cells were then reseeded in 24-well plates or T25 flasks (Corning, Inc., Corning, NY). The purity of the cells was assessed by immunocytochemistry using the monoclonal antibody OX-42 (a microglial marker for complement type 3 receptor) and anti-glial fibrillary acidic protein antibodies (GFAP) (an astrocyte marker). Cellular morphology was examined under a phase-contrast microscope.

\section{Assessment of viabilities by MTT assay}

For MTT assay, microglia $\left(2.5 \times 10^{4}\right.$ cells in $200 \mu \mathrm{l} /$ well $)$ were seeded in 96-well plates for $24 \mathrm{~h}$ and treated with various stimuli for $48 \mathrm{~h}$. After the treatment, the medium was removed and MTT $(5 \mathrm{mg} / \mathrm{mL}, 20 \mu \mathrm{l} /$ well $)$ was added, followed by incubation at $37^{\circ} \mathrm{C}$ for $4 \mathrm{~h}$. Afterward, supernatants were carefully removed and DMSO (150 $\mu \mathrm{l} /$ well, Sigma-Aldrich, St. Louis, MO) was added to the cells. After insoluble crystals were completely dissolved, absorbance at $490 \mathrm{~nm}$ was measured using Thermomax microplate reader (Molecular Devices).

\section{GA-Induced Retinal Microglial Activation}

Purified microglial cells were seeded into T25 flasks. After $48 \mathrm{~h}$ of growth, the cells were incubated with serum-free DMEM/F-12 containing 0, 10, 50, 100, or $250 \mu \mathrm{g} / \mathrm{mL}$ human GA for $24 \mathrm{~h}$. The GA used in this study (glycated human serum albumin from SigmaAldrich) was made less than 1 week prior as described by Baynes et al. [41], and contained 2.7-3.5 mol of fructoselysine per mol of albumin. No measurable AGEs were detected in these products by fluorescence assay (from 360 to $600 \mathrm{~nm}$ ) with excitation at 370 or $350 \mathrm{~nm}$, or by Western blot analysis $[18,53,54]$. To rule out the possible effects of lipopolysaccharide (LPS) contamination as a potential activator of microglia, microglial cells were also incubated with $250 \mu \mathrm{g} /$ $\mathrm{mL}$ GA for $24 \mathrm{~h}$ in the absence or presence of $10 \mu \mathrm{g} /$ mL PMXB (Sigma-Aldrich). Each experiment was performed in triplicate.

\section{M-CSF Treatment}

Recombinant murine M-CSF (R\&D Systems, Minneapolis, MN) was added at a concentration of $50 \mathrm{ng} / \mathrm{mL}$ to the cell medium with or without $250 \mu \mathrm{g} / \mathrm{mL}$ human GA. The cells were then allowed to grow for $24 \mathrm{~h}$.

\section{M-CSF and CSF-1R Neutralization}

For neutralization, $1 \mu \mathrm{g} / \mathrm{mL}$ anti-M-CSF or anti-CSF-1R antibodies (Santa Cruz Biotechnology, Santa Cruz, CA) were added to the cell medium. After $2 \mathrm{~h}$ of preincubation at $37^{\circ} \mathrm{C}$, an additional $250 \mu \mathrm{g} / \mathrm{mL}$ human $\mathrm{GA}$ were added to the medium.

\section{Immunocytochemistry}

For immunocytochemistry, 12-mm glass coverslips coated with poly L-lysine were used. Cells were fixed with $4 \%$ paraformaldehyde in $0.1 \mathrm{M}$ phosphate buffer for $15 \mathrm{~min}$ at room temperature, washed in $0.01 \mathrm{M}$ phosphate-buffered saline (PBS, $\mathrm{pH}$ 7.4), blocked in 5\% bovine serum for $30 \mathrm{~min}$, and incubated overnight with the primary antibodies. The following antibodies were used: OX-42 (1:200 dilution; Chemicon, Temecula, CA), Iba1 (1:200; Abcam, Cambridge, UK), M-CSF (1:100; Santa Cruz Biotechnology), and CSF-1R (1:100; Santa Cruz Biotechnology). After three rinses with $0.01 \mathrm{M}$ PBS, fluorescein isothiocyanate (FITC)-conjugated antimouse antibodies (1:200; Sigma-Aldrich), tetramethyl rhodamine isothiocyanate (TRITC)-conjugated anti-goat antibodies (1:200; KPL), or Cy3/IgG-conjugated antirabbit antibodies (1:200; Sigma-Aldrich) were added as secondary antibodies, and the cells were incubated at $37^{\circ} \mathrm{C}$ for $1 \mathrm{~h}$. To visualize the nuclei, 4', 6-diamidino-2phenylindole (DAPI, 1:500; Sigma-Aldrich) was used. Images were acquired using a fluorescence microscope or laser confocal microscope (TCS SP2; Leica Microsystems, 
Mannheim, Germany). The optical sections were reconstructed with a maximum projection using the software provided with the microscope (Leica Microsystems).

\section{Real-Time PCR}

Purified microglial cells were starved of serum for $6 \mathrm{~h}$ and then restimulated with graded GA for $24 \mathrm{~h}$. The microglia was then sorted into RNA lysis buffer, frozen on dry ice, and kept at $-80^{\circ} \mathrm{C}$ until processing. Total RNA was isolated with Trizol reagent (Invitrogen). The quality and quantity of the RNA were determined using a biophotometer (DU 800; Beckman Coulter, Fullerton, CA).

Rat retinal cDNA was prepared from $2 \mu \mathrm{g}$ of total RNA using SuperScript ${ }^{\mathrm{TM}}$ reverse transcriptase (RT; Life Technologies, Grand Island, NY). Briefly, isolated RNA was incubated with $50 \mu \mathrm{M}$ oligo (dT) 20, $10 \mathrm{mM}$ dNTP mix, and DEPC-treated water at $65^{\circ} \mathrm{C}$ for $5 \mathrm{~min}$. Next, $10 \mu \mathrm{l}$ of cDNA synthesis mix $(10 \times$ RT buffer, $25 \mathrm{mM}$ $\mathrm{MgCl}_{2}, 0.1 \mathrm{M} \mathrm{DTT}, 40 \mathrm{U} / \mu \mathrm{l}$ RNaseOUT, and $200 \mathrm{U} / \mu \mathrm{l}$ SuperScript ${ }^{\mathrm{TM}}$ III RT) were added to the reaction, followed by incubation with oligo (dT) 20 at $50^{\circ} \mathrm{C}$ for $50 \mathrm{~min}$, then incubation with random hexamer at $25^{\circ} \mathrm{C}$ for $10 \mathrm{~min}$, and finally incubation at $50^{\circ} \mathrm{C}$ for another $50 \mathrm{~min}$. The reactions were terminated by treatment at $85^{\circ} \mathrm{C}$ for $5 \mathrm{~min}$, and the mixtures were chilled. RNase $\mathrm{H}$ was added to each sample, and the mixture was incubated for $20 \mathrm{~min}$ at $37^{\circ} \mathrm{C}$.

The synthesis of cDNA was achieved using the following: CSF-1R sense, 5'-GCCTTTGGTCTGGGCAAA-3'; CSF-1Rantisense, 5'-AGCCGTGGACTTGAGCATCT-3'; and TaqMan probe, 5'-FAM-AAGATGCAGTGCTGAAGGTGGCTGTG-TAMRA-3'. The primers and probe were designed using Primer Express software (ver2.0; PE Applied Biosystems, Foster City, CA). Quantitative PCR amplification was carried out on a real-time PCR machine (Applied Biosystems 7500 real-time PCR system), using an initial incubation for $2 \mathrm{~min}$ at $95^{\circ} \mathrm{C}$ followed by 40 cycles of $15 \mathrm{~s}$ at $95^{\circ} \mathrm{C}$ and $45 \mathrm{~s}$ at $60^{\circ} \mathrm{C}$. The mRNA level of CSF-1R was standardized against the $\beta$-actin mRNA level in the same RNA sample. Each experiment was performed three times.

\section{Immunoprecipitation and Western Blotting}

Cells were collected and lysed in lysis buffer [50mM Tris$\mathrm{HCl}, \mathrm{pH}$ 7.5, 1mM EDTA, 0.1\% SDS, $150 \mathrm{mM} \mathrm{NaCl}$, $5 \mathrm{mM} \mathrm{NaF}, 0.5 \%$ sodium deoxycholate, 1\% Nonidet P-40, and $1 \%$ protease inhibitor cocktail (Sigma-Aldrich)]. The lysates were centrifuged at $14,000 \times g$ for $10 \mathrm{~min}$ at $4{ }^{\circ} \mathrm{C}$ and precleared by incubation with $25 \mu \mathrm{l}$ of protein A/GSepharose beads (GE Healthcare, Piscataway, NJ) and $2 \mu \mathrm{g}$ of normal murine serum at $4^{\circ} \mathrm{C}$ for $1 \mathrm{~h}$. The precleared lysates were then mixed with $5 \mu \mathrm{g}$ of anti-CSF-1R antibodies and $20 \mu \mathrm{l}$ of protein A/G-Sepharose beads as described above and incubated overnight with gentle rocking at $4^{\circ} \mathrm{C}$. The beads were isolated by centrifugation and washed four times with cell lysis solution. The bound proteins were subjected to $8 \%$ SDS-PAGE and transferred to a polyvinylidene difluoride (PVDF) membrane (Millipore, Billerica, MA). After incubation for $1 \mathrm{~h}$ in blocking solution (5\% nonfat dry milk in $0.1 \%$ TBST buffer), the membrane was incubated overnight at $4^{\circ} \mathrm{C}$ in blocking buffer containing the respective antibody (antiphospho-CSF-1R(Tyr723),1:200; Cell Signaling Technology; anti-CSF-1R, 1:200, Santa Cruz Biotechnology). The membrane was then washed three times and incubated with horseradish peroxidase-conjugated goat anti-rabbit antibodies (1:2,000; Santa Cruz Biotechnology) in blocking buffer for $2 \mathrm{~h}$ at room temperature. The bound antibodies were detected using an enhanced chemiluminescence system (ECL; GE Healthcare) and X-ray film. Densitometric analysis of each sample was performed using ImageMasterRVDS (GE Healthcare).

\section{Enzyme-Linked Immunosorbent Assay (ELISA)}

Purified microglial cells were incubated overnight in 24 -well plates at $2.5 \times 10^{5}$ cells per well in $1 \mathrm{~mL}$ of serum-free medium with or without graded GA. The supernatant was collected at the indicated times after treatment with the conditioned medium from the control and experimental groups, and the amounts of TNF- $\alpha$, IL$1 \beta$, and M-CSF were quantified by ELISAs (Biosource, Inc., Camarillo, CA), in accordance with the manufacturer's instructions. Each experiment was performed three times.

\section{Statistical Analysis}

Statistical analyses were performed using one-way ANOVA, followed by post-hoc analysis with the Bonferroni (equal variances assumed) or Dunnett's test (equal variances not assumed). All quantitative data are presented as the mean \pm SD. Values of $\mathrm{P}<0.05$ were considered statistically significant.

\section{Acknowledgements \\ This work was supported by grants from the National Basic Research Program of China (973 program), (2007 CB512205), National Basic Research grants of China $(30872825,2008)$ and Plan of the Best Disciplines Leaders in Shanghai (09XD1400900). The authors thank WY, ZSH, XP, and WJH for skillful technical supports.}

\section{Author details}

'Department of Opthalmology, EENT Hospital, Eye Institute, Fudan University, Shanghai, 200031, China. ${ }^{2}$ Institute of Brain Science, Fudan University, Shanghai, 200031, China

\section{Authors' contributions}

LW performed the experiments, designed the protocol, performed the statistical analysis and drafted the manuscript. XGZ and JCH designed the protocol and coordinated the study. TJ participated in the microglial culture. All authors have read and approved the final manuscript. 


\section{Competing interests}

The authors declare that they have no competing interests.

Received: 22 December 2010 Accepted: 25 January 2011 Published: 25 January 2011

\section{References}

1. Barber AJ, Antonetti DA, Kern TS, Reiter CE, Soans RS, Krady JK, Levison SW, Gardner TW, Bronson SK: The Ins2Akita mouse as a model of early retinal complications in diabetes. Invest Ophthalmol Vis Sci 2005, 46:2210-2218.

2. Krady JK, Basu A, Allen CM, XU Y, LaNoue KF, Gardner TW, Levison SW: Minocycline reduces proinflammatory cytokine expression, microglial activation, and caspase-3 activation in a rodent model of diabetic retinopathy. Diabetes 2005, 54:1559-1565.

3. Rungger-Brändle E, Dosso AA, Leuenberger PM: Glial reactivity, an early feature of diabetic retinopathy. Invest Ophthalmol Vis Sci 2000 41:1971-1980.

4. Zeng HY, Green WR, Tso MO: Microglial activation in human diabetic retinopathy. Arch Ophthalmol 2008, 126:227-232

5. Block ML, Zecca L, Hong JS: Microglia-mediated neurotoxicity: uncovering the molecular mechanisms. Nat Rev Neurosci 2007, 8:57-69.

6. Garden GA, Möller T: Microglia biology in health and disease. J Neuroimm Pharmacol 2006, 1:127-137.

7. Kim SU, de Vellis J: Microglia in health and disease. J Neurosci Res 2005, 81:302-313.

8. Wang AL, Yu AC, He QH, Zhu X, Tso MO: AGEs mediated expression and secretion of TNF alpha in rat retinal microglia. Exp Eye Res 2007, 84:905-913.

9. Ahmed N: Advanced glycation endproducts-role in pathology of diabetic complications. Diabetes Res Clin Pract 2005, 67:3-21.

10. Negoro H, Morley JE, Rosenthal MJ: Utility of serum fructosamine as a measure of glycemia in young and old diabetic and nondiabetic subjects. Am J Med 1988, 85:360-364.

11. Cohen MP, Hud E, Wu VY, Ziyadeh FN: Glycated albumin modified by Amadori adducts modulates aortic endothelial cell biology. Mol Cell Biochem 1995, 143:73-79.

12. Cohen MP, Ziyadeh FN, Lautenslager GT, Cohen JA, Shearman CW: Glycated albumin stimulation of PKC-beta activity is linked to increased collagen IV in mesangial cells. Am J Physiol 1999, 276:F684-F690.

13. Ruggiero-Lopez D, Rellier N, Lecomte M, Lagarde M, Wiernsperger N: Growth modulation of retinal microvascular cells by early and advanced glycation products. Diabetes Res Clin Pract 1997, 34:135-142.

14. Schalkwijk CG, Ligtvoet $N$, Twaalfhoven $H$, Jager $A$, Blaauwgeers $H G$, Schlingemann RO, Tarnow L, Parving HH, Stehouwer CD, van Hinsbergh WW: Amadori albumin in type 1 diabetic patients: correlation with markers of endothelial function, association with diabetic nephropathy, and localization in retinal capillaries. Diabetes 1999 48:2446-2453.

15. Cohen MP, Hud E, Wu VY, Shearman CW: Amelioration of diabetesassociated abnormalities in the vitreous fluid by an inhibitor of albumin glycation. Invest Ophthalmol Vis Sci 2008, 49:5089-5093.

16. Kim J, Kim KS, Shinn JW, Oh YS, Kim HT, Jo I, Shinn SH: The effect of antioxidants on glycated albumin-induced cytotoxicity in bovine retinal pericytes. Biochem Biophys Res Commun 2002, 292:1010-1016.

17. Bian ZM, Elner SG, Strieter RM, Glass MB, Lukacs NW, Kunkel SL, Elner VM: Glycated serum albumin induces chemokine gene expression in human retinal pigment epithelial cells. J Leukoc Biol 1996, 60:405-414

18. Bian ZM, Elner VM, Yoshida A, Kunkel SL, Elner SG: Signaling pathways for glycated human serum albumin-induced IL- 8 and MCP-1 secretion in human RPE cells. Invest Ophthalmol Vis Sci 2001, 42:1660-1668.

19. Brandt R, Landmesser C, Vogt L, Hehmke B, Hanschke R, Kasbohm J, Hartmann K, Jäger B, Krantz S, Michaelis D: Differential expression of fructosyllysine-specific receptors on monocytes and macrophages and possible pathophysiological significance. Diabetologia 1996, 39:1140-1147.

20. Salazar R, Brandt R, Krantz $S$ : Expression of fructosyllysine receptors on human monocytes and monocyte-like cell lines. Biochim Biophys Acta 1995, 1266:57-63.

21. Salazar R, Brandt R, Krantz S: Binding of Amadori glucose-modified albumin by the monocytic cell line MonoMac 6 activates protein kinase $\mathrm{C}$ epsilon protein tyrosine kinases and the transcription factors AP- 1 and NF-kappaB. Glycoconj J 2001, 18:769-777.
22. Cohen MP, Shea E, Chen S, Shearman CW: Glycated albumin increases oxidative stress, activates NF-kappa B and extracellular signal-regulated kinasee (ERK), and stimulates ERK-dependent transforming growth factorbeta 1 production in macrophage RAW cells. J Lab Clin Med 2003, 141:242-249

23. Michaelson MD, Bieri PL, Mehler MF, Xu H, Arezzo JC, Pollard JW, Kessler JA CSF-1 deficiency in mice results in abnormal brain development. Development 1996, 122:2661-2672.

24. Théry C, Hétier E, Evrard C, Mallat M: Expression of macrophage colonystimulating factor gene in the mouse brain during development. Neurosci Res 1990, 26:129-133.

25. Chitu V, Stanley ER: Colony-stimulating factor-1 in immunity and inflammation. Curr Opin Immunol 2006, 18:39-48.

26. Murphy GM Jr, Zhao F, Yang L, Cordell B: Expression of macrophage colony-stimulating factor receptor is increased in the ABPP ${ }^{(\mathrm{V} 717 \mathrm{~F})}$ transgenic mouse model of Alzheimer's disease. Am J Pathol 2000, 157:895-904.

27. Raivich G, Haas S, Werner A, Klein MA, Kloss C, Kreutzberg GW: Regulation of MCSF receptors on microglia in the normal and injured mouse central nervous system: a quantitative immunofluorescence study using confocal laser microscopy. J Comp Neurol 1998, 395:342-358.

28. Takeuchi A, Miyaishi O, Kiuchi K, Isobe K: Macrophage colony-stimulating factor is expressed in neuron and microglia after focal brain injury. J Neurosci Res 2001, 65:38-44.

29. Wang Y, Berezovska O, Fedoroff S: Expression of colony stimulating factor-1 receptor (CSF-1R) by CNS neurons in mice. J Neurosci Res 1999, 57:616-632.

30. Mitrasinovic OM, Murphy GM Jr: Accelerated phagocytosis of amyloidbeta by mouse and human microglia overexpressing the macrophage colony-stimulating factor receptor. J Biol Chem 2002, 277:29889-29896

31. Mitrasinovic OM, Robinson CC, Tenen DG, Lee YL, Poon C, Murphy GM Jr: Biolistic expression of the macrophage colony stimulating factor receptor in organotypic cultures induces an inflammatory response. $J$ Neurosci Res 2004, 77:420-429.

32. Elner SG, Elner VM, Jaffe GJ, Stuart A, Kunkel SL, Strieter RM: Cytokines in proliferative diabetic retinopathy and proliferative vitreoretinopathy. Curr Eye Res 1995, 14:1045-1053.

33. Saini A, Liu YJ, Cohen DJ, Ooi BS: Hyperglycemia augments macrophage growth responses to colony-stimulating factor-1. Metabolism 1996, 45:1125-1129.

34. Imai Y, Kohsaka S: Intracellular signaling in M-CSF-induced microglia activation: role of Iba1. Glia 2002, 40:164-174.

35. Weinstein JR, Swarts S, Bishop C, Hanisch UK, Möller T: Lipopolysaccharide is a frequent and significant contaminantin microglial-activating factors. Glia 2008, 56:16-26.

36. Antonetti DA, Barber AJ, Bronson SK, Freeman WM, Gardner TW, Jefferson LS, Kester M, Kimball SR, Krady JK, LaNoue KF, Norbury CC, Quinn PG, Sandirasegarane L, Simpson IA: Diabetic retinopathy: seeing beyond glucose-induced microvascular disease. Diabetes 2006, 55:2401-2411.

37. Kern TS: Contributions of inflammatory processes to the development of the early stages of diabetic retinopathy. Exp Diabetes Res 2007, 95103.

38. Schalkwijk CG, Lieuw-a-Fa M, van Hinsbergh WW, Stehouwer CD: Pathophysiological role of Amadori-glycated proteins in diabetic microangiopathy. Semin Vasc Med 2002, 2:191-197.

39. Vinores SA, Gadegbeku C, Campochiaro PA, Green WR: Immunohistochemical localization of blood-retinal barrier breakdown in human diabetics. Am J Pathol 1989, 134:231-235.

40. Vinores SA, McGehee R, Lee A, Gadegbeku C, Campochiaro PA: Ultrastructural localization of blood-retinal barrier breakdown in diabetic and galactosemic rats. J Histochem Cytochem 1990, 38:1341-1352.

41. Baynes JW, Thorpe SR, Murtiashaw MH: Nonenzymatic glucosylation of lysine residues in albumin. Methods Enzymol 1984, 106:88-98.

42. Cohen MP, Ziyadeh FN: Amadori glucose adducts modulate mesangial cell growth and collagen gene expression. Kidney Int 1994, 45:75-84.

43. Salazar R, Brandt R, Kellermann J, Krantz S: Purification and characterization of a $200 \mathrm{kDa}$ fructosyllysine-specific binding protein from cell membranes of U937 cells. Glycoconj J 2001, 17:713-716.

44. Chow F, Ozols E, Nikolic-Paterson DJ, Atkins RC, Tesch GH: Macrophages in mouse type 2 diabetic nephropathy: correlation with diabetic state and progressive renal injury. Kidney Int 2004, 65:116-128. 
45. Wautier MP, Boulanger E, Guillausseau PJ, Massin P, Wautier JL: AGEs, macrophage colony stimulating factor and vascular adhesion molecule blood levels are increased in patients with diabetic microangiopathy. Thromb Haemost 2004, 91:879-885.

46. Liu W, Xu GZ, Jiang CH, Da CD: Expression of macrophage colonystimulating factor (M-CSF) and its receptor in streptozotocin-induced diabetic rats. Curr Eye Res 2009, 34:123-133.

47. Calvo CF, Dobbertin A, Gelman M, Glowinski J, Mallat M: Identification of CSF-1 as a brain macrophage migratory activity produced by astrocytes. Glia 1998, 24:180-186.

48. Liu W, Brosnan CF, Dickson DW, Lee SC: Macrophage colony-stimulating factor mediates astrocyte-induced microglial ramification in human fetal central nervous system culture. Am J Pathol 1994, 145:48-53.

49. Umeda S, Takahashi K, Shultz LD, Naito M, Takagi K: Effects of macrophage colony-stimulating factor on macrophages and their related cell populations in the osteopetrosis mouse defective in production of functional macrophage colony-stimulating factor protein. Am J Pathol 1996, 149:559-574

50. Shafit-Zagardo B, Sharma N, Berman JW, Bornstein MB, Brosnan CF: CSF-1 expression is up-regulated in astrocyte cultures by IL-1 and TNF and affects microglial proliferation and morphology in organotypic cultures. Int J Dev Neurosci 1993, 11:189-198.

51. Hassan NF, Rifat S, Campbell DE, McCawley LJ, Douglas SD: Isolation and flow cytometric characterization of newborn mouse brain-derived microglia maintained in vitro. J Leuk Biol 1991, 50:86-92.

52. Roque RS, Caldwell RB: Isolation and culture of retinal microglia. Curr Eye Res 1993, 12:285-290.

53. Gilcrease MZ, Hoover RL: Activated human monocytes exhibit receptormediated adhesion to a non-enzymatically glycosylated protein substrate. Diabetologia 1990, 33:329-333.

54. Wolff SP, Jiang ZY, Hunt JV: Protein glycation and oxidative stress in diabetes mellitus and ageing. Free Radic Biol Med 1991, 10:339-352.

doi:10.1186/1471-2121-12-5

Cite this article as: Liu et al: Macrophage colony-stimulating factor and its receptor signaling augment glycated albumin-induced retinal microglial inflammation in vitro. BMC Cell Biology 2011 12:5.

\section{Submit your next manuscript to BioMed Central} and take full advantage of:

- Convenient online submission

- Thorough peer review

- No space constraints or color figure charges

- Immediate publication on acceptance

- Inclusion in PubMed, CAS, Scopus and Google Scholar

- Research which is freely available for redistribution

Submit your manuscript at www.biomedcentral.com/submit
Ciomed Central 